\title{
Indenização do erro judiciário e prisão indevida
}

\begin{abstract}
RESUMO
O enfoque especial deste tema é a Indenização do erro judiciário e prisão indevida (art. $5^{\circ}$, $L X X V$, e art. 37, $\S 6^{\circ}$, da Constituição Federal) aos danos decorrentes de atos jurisdicionais, mais especificamente o erro judiciário e a prisão indevida, que deverão ser suportados pelo Estado. Na concretização da função jurisdicional (não somente judicial ou administrativa), o Estado-juiz, por vezes, gera graves prejuízos aos jurisdicionados, levando-os a suportar um ônus indevido, notadamente nos casos de funcionamento do serviço judiciário, como a demora na prestação jurisdicional, o erro judiciário, a prisão indevida, erro judiciário fora da hipótese clássica, a atuação culposa ou dolosa do magistrado ou mesmo a denegação da justiça. A exigência de reparação dos erros dos juízes assenta em pressuposto jurídico-político indiscutível. Assim, a importância do tema escolhido, ou seja, a responsabilidade civil do Estado por atos jurisdicionais, o novo conteúdo do artigo 630 do Código de Processo Penal, é concernente à responsabilidade do Poder Público por ato jurisdicional, ou seja, ato praticado por juiz ou tribunal judiciário em sua função específica de elaboração e entrega da prestação jurisdicional; ato que, viciado, cause dano pessoal, moral ou patrimonial ao administrado, uma vez que o exame desse dispositivo constitucional (art. $5^{\circ} \mathrm{LXXV}$, e art. 37, § $6^{\circ}$, da C.F.) revela que o constituinte estabeleceu para todas as entidades estatais e seus desmembramentos administrativos a obrigação de reparar, de indenizar o dano causado - inclusive em decorrência de atos jurisdicionais - a terceiros, por seus servidores, independentemente da prova da culpa no cometimento da lesão, ou à própria vítima de erro judiciário ou privação indevida de sua liberdade, isto é, a indenização por erro judiciário decorrente da aplicação da lei, a indenização como fundamento do Estado de Direito, a culpa do serviço público e o erro judiciário como fundamentos para a responsabilidade estatal, e a ação direta independentemente de prévia rescisão do julgado. É o que determina a nova regra constitucional do art. 5\%, LXXV, da Constituição Federal (CF): "O Estado indenizará o condenado por erro judiciário, assim como o que ficar preso além do tempo fixado na sentença". Acrescente-se que a nova regra do dispositivo constitucional não depende de ter havido prisão, bastando a condenação errônea, para ser postulada a reparação dos danos materiais e morais porventura decorrentes da atividade jurisdicional.
\end{abstract}




\section{RÉSUMÉ}

Le but particulier de ce travail est l'indemnisation de l'erreur judiciaire et l'arrestation injuste (art. $5^{\mathrm{e}}, \mathrm{LXXV}$, et art. 37, $\S 6^{\mathrm{e}}$ de la Constitution Fédérale) aux dommages provenants d'actes juridictionnels, plus spécifiquement d'erreur judiciaire, et arrestation injuste, qui doivent être subis par l'Etat. Dans la concretisation de la fonction juridictionnelle (et non seulement dans la fonction judiciaire ou administrative), l'État-juge produit parfois de graves préjudices aux juridictionnés, les menant à subir une charge indue, notament dans les cas de fonctionnement du service judiciaire, comme le retard dans la prestation juridictionnelle, l'erreur judiciaire, l'arrestation indue, l'erreur judiciaire hors de l'hypothèse classique, l'action criminelle ou fraudulente du magistrat ou même la dénégation de la justice. L'exigence de réparation des erreurs des juges est basée sur un présupposé juridico-politique indiscutable. L'importance du sujet choisi, c'est-à-dire, la responsabilité civile de l'État par des actes juridictionnels, le nouveau contenu de l'article $630 \mathrm{du}$ Code du Procès Pénal a trait à la responsabilité du Pouvoir Public par acte juridictionnel, c'est-à-dire, l'acte pratiqué par un juge ou tribunal judiciaire dans sa fonction spécifique d'élaboration et remise de prestation juridictionnelle, qu'une fois corrompu cause dommage personnel, moral ou patrimonial à l'administré. L'examen de ce dispositif constitutionnel (art. $5^{\mathrm{e}} \mathrm{LXXV}$, et art. $37, \S 6^{\mathrm{e}}$, de la CF) révèle que le constituant a établi, pour toutes les entités de l'État et ses démembrements admininstratifs, l'obligation de réparer, d'indemniser le préjudice causé à des tiers par leurs serviteurs - y inclus découlés d'actes juridictionnels - indépendamment de preuve de culpabilité dans l'exécution de la lésion, ou à la victime elle-même d'erreur judiciaire ou privation indue de sa liberté, c'est-à-dire, l'indemnisation par erreur judiciaire advenue de l'application de la loi, l'indemnisation comme base de l'État de Droit, la culpabilité du service public et l'erreur judiciaire comme principal appui pour la responsabilité de l'État, et l'action directe indépendamment de rescision préalable du jugé. C'est ce qui détermine la nouvelle règle constitutionnelle de l'art. $5^{\mathrm{e}}$, LXXV, de la CF : «L'État indemnisera le condamné par erreur judiciaire, ainsi que celui qui est gardé en prison au-delà du temps fixé par l'arrêt ». On peut ajouter que la nouvelle règle du dispositif constitutionnel ne dépend pas du fait d'avoir eu l'arrestation ; la condemnation erronée est suffisante pour une demande de réparation des dommages matériels et moraux qui puissent être provenants de l'activité juridictionnelle. 


\section{INTRODUÇÃO}

A responsabilidade civil é um dos temas mais fascinantes do ordenamento jurídico, em especial a responsabilidade extracontratual. A questão focalizada nesta tese consiste em saber como era tratado, antes da Carta Constitucional de 1988, o tema referente à responsabilidade do Estado por atos de seus agentes, e como é tratado nos dias de hoje, tanto na doutrina pátria como no Direito estrangeiro, na legislação e na jurisprudência.

O princípio da responsabilidade objetiva estatal - hoje consagrado no art. 37, $\S 6^{\circ}$, da Constituição da República de 1988 - já era previsto no art. 194 da Constituição de 1946. Os autores são unânimes em reconhecê-lo, havendo, mesmo, certa uniformidade na argumentação: se o elemento culpa é previsto (parágrafo único do art. 194 da CF de 1946, do art. 105 da CF de 1967 e do art. 107 da CF de 1969; segunda parte do art. 37, § 6º da CF de 1988) apenas para assegurar a ação regressiva das pessoas jurídicas contra os funcionários causadores do dano, quando tiver havido dolo ou culpa deles; daí resulta, por exclusão, que, omitindo-se o corpo do artigo quanto a referir-se ao elemento subjetivo, ficará estabelecido que essas entidades devem reparar o dano mesmo sem culpa, em qualquer caso.

A responsabilidade de que tratamos é a extracontratual do Estado, para restringir a temática, ficando a responsabilidade contratual fora da análise desta tese, uma vez que, de ordem contratual, deve ser analisada pela ótica dos contratos administrativos.

Finalmente, os pressupostos necessários à responsabilização do Estado: a ação ou omissão humana imputável ao Estado ou à pessoa de direito privado prestadora de serviços públicos; atos lícitos ou ilícitos; nexo causal, que significa a referibilidade jurídica ao Estado do evento danoso; dano causado pelo agente e imputável ao Estado, dano material e moral.

Também será desenvolvida a responsabilidade civil do Estado em linhas gerais; a evolução histórica da responsabilidade civil extracontratual do Estado; as diversas teorias aplicadas à responsabilidade civil do Estado; a responsabilidade subjetiva e a objetiva; a regra no direito brasileiro: responsabilidade objetiva do Estado e subjetiva do agente; responsabilidade civil do Estado e do agente público; responsabilidade inominada do Estado; danos indenizáveis; excludentes de responsabilidade e regressividade.

Abordar-se-á, também, embora de forma resumida, a teoria publicista, o primeiro passo no sentido da evolução de teorias de responsabilidade do Estado segundo os princípios 
do direito público, que foi dado pela jurisprudência francesa, com o famoso caso Blanco, em 1873, a partir do qual começaram a surgir as teorias publicistas da responsabilidade do Estado: teoria da culpa do serviço ou teoria da culpa administrativa e a teoria do risco, desdobrada, segundo alguns autores, em teoria do risco administrativo e teoria do risco integral. Há também a teoria da culpa do serviço, também chamada de culpa administrativa, ou teoria do acidente administrativo. Na hipótese de não se identificar o funcionário causador do dano, há a teoria da culpa anônima do serviço público.

O princípio fundamental em que se repousa a teoria do risco administrativo, no direito brasileiro, é o denominado princípio da igualdade dos ônus e encargos, consagrando a norma constitucional à teoria da responsabilidade objetiva do Estado, que é a regra estabelecida no art. 37, $\S 6^{\circ}$, da Constituição Federal de 1988: responsabilidade objetiva do Estado e da responsabilidade subjetiva do agente público, que exige o direito de regresso do Estado contra o agente causador do dano, se este agiu com culpa ou dolo.

Outro ponto a ser abordado é a obrigatoriedade - ou não - da denunciação da lide, a que se refere o art. 70, inciso III, do Código de Processo Civil, instaurando-se um eventual litisconsórcio passivo, ou se a Fazenda Pública poderá chamar, ao processo, o funcionário faltoso, na forma do art. 77, III, do mesmo estatuto processual. O tema é controverso, não obstante a clareza do dispositivo constitucional do art. 37, § $6^{\circ}$, da Constituição Federal de 1988. O Supremo Tribunal Federal tem entendido e vem decidindo que a ação deve ser proposta contra a pessoa jurídica e não contra o agente público, nem mesmo em litisconsórcio ${ }^{1}$.

Por outro lado, enfoque especial será dado aos danos decorrentes de atos jurisdicionais, mais especificamente erro judiciário, e prisão indevida.

$\mathrm{Na}$ concretização da função jurisdicional (não somente na judicial ou administrativa), o Estado-juiz, por vezes, gera graves prejuízos aos jurisdicionados, levandoos a suportar um ônus indevido, notadamente nos casos de funcionamento do serviço judiciário, como a demora na prestação jurisdicional, o erro judiciário, a prisão indevida, erro judiciário fora da hipótese clássica (art. 630, do CPP), a atuação culposa ou dolosa do magistrado ou mesmo a denegação da justiça. Bielsa, estudando o problema do erro judiciário, começa por observar que não é possível compreender o sistema integral de justiça sem que se atenda ao sacrifício individual injusto. A exigência de reparação dos erros dos

\footnotetext{
${ }^{1}$ RE 327.904/SP, rel. Min. Carlos Ayres Brito (DJ 8.9.06), STF. No mesmo sentido: RE 344.133, em que foi relator o Min. Marco Aurélio.
} 
juízes assenta em pressuposto jurídico-político indiscutível: “A mesma solidariedade que nasce em face do perigo e do delito deve surgir ante a inocência castigada" ${ }^{2}$.

As teorias acerca da responsabilidade civil sofreram notória evolução jurídica. Em se tratando de Responsabilidade Civil do Estado, há grandes controvérsias e incertezas na ciência jurídica, fazendo com que doutrina e jurisprudência não consigam consagrar um entendimento pacífico, principalmente quando o prejuízo decorre de erro judicial. A questão da responsabilidade civil estatal pelos atos jurisdicionais ainda é objeto de inconciliáveis posicionamentos tanto na doutrina quanto na jurisprudência.

Com o novo status que lhe deu o art. $5^{\circ}$, LXXV, da CF, a partir de 5 de outubro de 1988, o direito do condenado à indenização foi pormenorizado de modo a abarcar o erro judiciário e a prisão além do tempo fixado na sentença: é a constitucionalização da matéria, que antes tinha assento na legislação infraconstitucional do art. 630 do Código de Processo Penal, que hoje pode ser invocada para abranger a hipótese de acusação meramente privada que o dispositivo expressamente excluía da obrigação estatal ( $\S 2^{\circ}$, letra "b”, do art. 630, do CPP), assim como para determinar a indenização pela privação da liberdade ainda quando não haja condenação. A Constituição Federal de 1988, art. 5º inciso LXXV, ao ordenar que o Estado indenizará o condenado por erro judiciário, assim como o que ficar preso além do prazo fixado na sentença, rompeu com a lamentável restrição aparente contida no Código de Processo Penal, no sentido de subordinar a reparação pelo erro judiciário à prévia revisão criminal. Agora, ficou claro e cristalino que o Estado deve indenizar a vítima do erro judiciário, dando lugar ao entendimento de que como tal deve ser interpretado todo erro que importe coação carcerária juridicamente errônea a cidadão inocente.

Quando se fala em erro judiciário, pensa-se de imediato na sentença criminal de condenação ilegítima, mas o erro judiciário por extensão abrange também a prisão preventiva injustificada ou detenção, sem justa causa, cujos danos patrimoniais e morais são patentes.

Há que se definir o erro judiciário como toda condenação injusta, incluindo o excesso e a insuficiência da pena e, para efeito de sua reparação, o erro da investigação policial. A definição, portanto, alcança, também, a prisão preventiva injustificada. Com efeito, nosso entendimento é de que não há base para excluí-la do direito à reparação. Se há erro judiciário em virtude da sentença condenatória, haverá também em consequência da prisão

\footnotetext{
${ }^{2}$ BIELSA, Rafael. "Las víctimas de los errores judiciales em las causas criminales y El derecho a La reparación”, In: Revista Universitária de Ciencias Juridicas y sociaales, Buenos Aires, p. 1, apud DIAS, José de Aguiar. Da responsabilidade civil do Estado. XI. ed. Rio de Janeiro: Renovar, 2006. p. 858; CAHALI, Yussef Said. Responsabilidade Civil do Estado. 3. ed. São Paulo: Revista dos Tribunais, 2007. p. 472.
} 
preventiva ou detenção. Isso quer dizer que, em outras palavras, a prisão por erro judiciário ou permanência do preso por tempo superior ao determinado na sentença, de acordo com o art. $5^{\circ}, \mathrm{LXXV}$, da CF, garante ao cidadão o direito à indenização.

Com efeito, não se compreende que, sendo injusta a prisão no que exceder o prazo fixado na sentença condenatória, seja, em tese, menos injusta a prisão do réu que nela é mantido se ao final vier a ser eventualmente julgada improcedente a denúncia pela sentença absolutória. Todavia, agora, essas situações foram corrigidas pela Lei n. 12.403/2011, editada com o escopo de se evitar o encarceramento do indiciado ou do acusado antes de transitar em julgado a sentença penal condenatória.

Hoje, antes da condenação definitiva, o sujeito só pode ser preso em três situações: flagrante delito, prisão preventiva e prisão temporária. Mas somente poderá permanecer preso nas duas últimas, não existindo mais a prisão em flagrante como hipótese de prisão cautelar garantidora do processo. Ninguém responde mais preso a processo em virtude da prisão em flagrante, a qual deverá ser convertida em prisão preventiva ou convolarse em liberdade provisória.

Enfim, antes da sentença final, é imprescindível a demonstração dos requisitos de necessidade e urgência para a prisão cautelar. Além da prisão temporária, cabível nas restritas hipóteses da Lei n. 7.960/89 e somente quando imprescindível para a investigação policial de alguns crimes elencados em rol taxativo, só existe a prisão preventiva como modalidade de prisão provisória. Mesmo assim, quando couberem outras medidas coercitivas menos drásticas, como, por exemplo, obrigação de comparecer ao fórum mensalmente, proibição de se ausentar da comarca, submeter-se ao monitoramento eletrônico etc., não se imporá a prisão preventiva, a qual passa a ser medida excepcional.

Aliás, atualmente, sem necessidade e urgência, nenhuma medida restritiva será imposta, devendo o juiz conceder a liberdade provisória, com ou sem fiança. Para pena igual ou inferior a 4 (quatro) anos, o delegado de polícia arbitra a fiança (no valor de 01 a 100 salários mínimos); já para pena máxima superior a 4 (quatro) anos, só o juiz pode fixar a fiança (no valor de 10 a 200 salários mínimos). Em se tratando de infrações inafiançáveis, como crimes hediondos, racismo, tráfico de drogas etc., não havendo necessidade de prisão preventiva, nem de providências cautelares alternativas, também caberá liberdade provisória.

Já foi reconhecido pelo STJ que se assemelha à hipótese de indenização por erro judiciário, a restrição preventiva da liberdade de alguém que posteriormente venha a ser absolvido. A prisão injusta revela ofensa à honra, à imagem, mercê de afrontar o mais comezinho direito fundamental à vida livre e digna. Além disso, posicionou-se no sentido de 
que a absolvição futura revela a ilegitimidade da prisão pretérita, cujos efeitos deletérios para a imagem e honra do homem são inequívocos (notória non egent probationem). É a magnitude ao status libertatis, que o constituinte de 1988 inscreveu no rol das chamadas franquias democráticas, uma regra expressa que obriga o Estado a indenizar o condenado por erro judiciário ou quem permanecer preso por tempo superior ao fixado pela sentença (CF, art. $\left.5^{\circ}, \mathrm{LXXV}\right)$, situações essas equivalentes às de quem é submetido à prisão processual e posteriormente absolvido.

Além do mais, no referido julgamento levado a efeito pelo STJ, de relatoria do Ministro Luiz Fux, também ficou estabelecido que é

forçoso convir que a situação de o cidadão ser submetido à prisão processual e depois absolvido é equivalente àquela em que o Estado indeniza o condenado por erro judiciário ou pelo fato de este permanecer preso além do tempo fixado na sentença. Forçoso, assim, concluir, que quando preso preventivamente o cidadão e depois é absolvido, in casu, pelo Tribunal do Júri, também se configura situação em que houve erro judiciário, sem que se tenha havido condenação ${ }^{3}$.

Nesse sentido:

Execução penal. Detração penal. Cômputo de tempo de prisão imposta em outro processo. Possibilidade. Condições. CP, art. 42. LEP, art. 111. cf, art. 5., XV e LXXV. A Constituição de República, em razão da magnitude conferida ao 'status libertatis' (art. 5., XV), inscreveu no rol dos direitos e garantias individuais regra expressa que obriga o estado a indenizar o condenado por erro judiciário ou quem permanecer preso por tempo superior ao fixado na sentença (art. 5., LXXV), situações essas equivalentes à de quem foi submetido à prisão processual e posteriormente absolvido.

- Em face desse preceito constitucional, o art. 42, do Código Penal, e o art. 111, da Lei das Execuções Penais, devem ser interpretados de modo a abrigar a tese de que o tempo de prisão provisória, imposta em processo no qual o réu foi absolvido, seja computado para a detração de pena imposta em processo relativo a crime anteriormente cometido.

- Recurso especial conhecido e desprovido (REsp 61899/SP; Rel. Min. Vicente Leal, da 6a Turma do STJ; DJ. 03.06.1996)

PROCESSO CIVIL. ERRO JUDICIÁRIO. ART. 5', LXXV, DA CF. PRISÃO PROCESSUAL. POSTERIOR ABSOLVIÇÃO. INDENIZAÇÃO. DANOS MORAIS.

1. A prisão por erro judiciário ou permanência do preso por tempo superior ao determinado na sentença, de acordo com o art. $5^{\circ}, \mathrm{LXXV}$, da CF, garante ao cidadão o direito à indenização.

2. Assemelha-se à hipótese de indenizabilidade por erro judiciário, a restrição preventiva da liberdade de alguém que posteriormente vem a ser absolvido. A prisão injusta revela ofensa à honra, à imagem, mercê de afrontar o mais comezinho direito fundamental à vida livre e digna. A absolvição futura revela a ilegitimidade da prisão pretérita, cujos efeitos

\footnotetext{
${ }^{3}$ REsp no 427.560-TO, Rel. Min. LuizFux, $1^{\text {a }}$ Turma do STJ, DJ 30/09/2002. Julgamento: 05-09-2002.
} 
deletérios para a imagem e honra do homem são inequívocos (notoria non egent probationem).

3. O pedido de indenização por danos decorrentes de restrição ilegal à liberdade inclui o 'dano moral', que in casu, dispensa prova de sua existência pela inequivocidade da ilegalidade da prisão, duradoura por nove meses. Pedido implícito, encartado na pretensão às 'perdas e danos'. Inexistência de afronta ao dogma da congruência (arts. $2^{\circ}$, 128 e 460, do CPC).

4. A norma jurídica inviolável no pedido não integra a causa petendi. 'O constituinte de 1988, dando especial relevo e magnitude ao status libertatis, inscreveu no rol das chamadas franquias democráticas uma regra expressa que obriga o Estado a indenizar o condenado por erro judiciário ou quem permanecer preso por tempo superior ao fixado pela sentença $\left(\mathrm{CF}\right.$, art. $5^{\circ}$, LXXV), situações essas equivalentes à de quem submetido à prisão processual e posteriormente absolvido'.

5. A fixação dos danos morais deve obedecer aos critérios da solidariedade e exemplaridade, que implica na valoração da proporcionalidade do quantum e na capacidade econômica do sucumbente.

6. Recurso especial desprovido (REsp 427.560/TO; Rel. Min. Luiz Fux, da $1^{\mathrm{a}}$ Turma do STJ; DJ. 30.09.2002).

Nesse sentido, ressalta-se o entendimento de Diogo de Figueiredo Moreira Neto, quando afirma peremptoriamente:

Não obstante, deve-se consignar o entendimento de que o Estado pode ser levado a responder pelos danos decorrentes da prisão preventiva, se houver posterior absolvição do acusado, o que parece consentâneo com o princípio da dignidade humana, que ficaria, assim, vulnerado pela medida acautelatória penal sem causa (art. $\left.1^{\circ}, \mathrm{III}, \mathrm{CF}\right)^{4}$.

É o que determina a nova regra constitucional do art. 5o, LXXV, da CF: "O Estado indenizará o condenado por erro judiciário, assim como o que ficar preso além do tempo fixado na sentença". Eis, pois, a importância do tema escolhido, ou seja, a responsabilidade civil do Estado por atos jurisdicionais, o novo conteúdo do artigo 630 do Código de Processo Penal, que agora pode ser invocado para abranger a hipótese de acusação privada, afastando a restrição contida no $\S 2^{\circ}$, alínea "b", dependendo, apenas, da satisfação dos pressupostos gerais da responsabilização estatal, uma vez que o exame desse dispositivo constitucional (o art. $5^{\circ}$, LXXV, c.c. o art. 37, $\S 6^{\circ}$, da CF) revela que o constituinte estabeleceu, para todas as entidades estatais e seus desmembramentos administrativos, a obrigação de reparar, de indenizar o dano causado a terceiros por seus servidores, independentemente da prova da culpa no cometimento da lesão, inclusive em decorrência de atos jurisdicionais que causem danos a terceiros, ou à própria vítima de erro judiciário ou privação indevida de sua liberdade, conforme regramento constitucional inscrito nos artigos

\footnotetext{
${ }^{4}$ MOREIRA NETO, Diogo de Figueiredo. Curso de Direito Administrativo. 14. ed. Rio de Janeiro: Forense, 2005 , p. 591.
} 
$5^{\circ}$, LXXV, e $37, \S 6^{\circ}$, da Constituição Federal, isto é, a indenização por erro judiciário decorrente da aplicação da lei, a indenização como fundamento do Estado de Direito, a culpa do serviço público e o erro judiciário como fundamentos para a responsabilidade estatal, e a ação direta independentemente de prévia rescisão do julgado.

Acrescente-se que a nova regra do dispositivo constitucional não depende de ter havido prisão, bastando a condenação errônea para ser postulada a reparação dos danos materiais e morais porventura decorrentes da atividade jurisdicional.

Sobre a justificativa do tema escolhido, não resta a menor dúvida de que a responsabilidade civil do Estado é um dos mais belos, ricos, fecundos e de mais profundo alcance dos institutos formadores da ciência do Direito. E, por isso mesmo, aquele que, talvez, mais cativa e, certamente, o que mais desafia a argúcia do pesquisador, conforme adverte Carlos Alberto Tavares Campista ${ }^{5}$.

Por si só, o tema genérico da responsabilidade civil do Estado por atos jurisdicionais é fascinante, sempre polêmico. Não se pretende pioneirismo na abordagem do tema proposto, visto que a tarefa é dificílima e impossível de se alcançar. Mas o que se pretende, com inaudito esforço, é ampliar o estudo e o debate do mesmo tema, já desenvolvidos por renomados autores, firmados em torno da responsabilidade civil do Estado por atos jurisdicionais e, particularmente, em torno do erro judiciário e prisão indevida, em sentido amplo.

A responsabilidade civil do Estado pelo erro judiciário representa o reforço da garantia dos direitos individuais. Na França, conforme assinala Bréchon-Moulènes, desde os fins do século XIX, os escândalos provocados por erros judiciários suscitaram veemente intervenção dos parlamentares, a fim de assegurar sua reparação, culminando com a Lei de 08.06.1895, reconhecendo a responsabilidade civil do Estado em matéria de erro judiciário ${ }^{6}$.

Eis, aí, em síntese, a breve exposição do tema que trata da responsabilidade civil extracontratual do Estado por erro judiciário e prisão indevida.

\footnotetext{
${ }^{5}$ CAMPISTA, Carlos Alberto Tavares. Pela indenização dos danos morais em caso de homicídio. $R F$ 287. Rio de Janeiro: Forense, 1984.

${ }^{6}$ BRÉCHON-MOULÈNES. Les regimes législatifs de responsabilité publique. Paris: Librairie Générale de Droit et de Jurisprudence, 1974, p. 69.
} 


\section{CONCLUSÃO: A OBRIGAÇÃO DE INDENIZAR DO ESTADO PELO ERRO JUDICIÁRIO E PELA PRISÃO INDEVIDA}

1. Finaliza-se o estudo do "erro judiciário" e da "prisão indevida", objeto desta tese, e nossa posição é no sentido da reparabilidade dos danos em geral decorrentes da prestação do serviço judiciário;

2. Não existindo causa apta para a privação da liberdade pessoal em definitivo, a prisão não é devida, impondo ao Estado o dever de indenizar, que, no direito brasileiro, tem amparo no art. 5', LXXV, da Constituição Federal, verbis: “O Estado indenizar o condenado por erro judiciário, assim como o que ficar preso além do tempo fixado na sentença", ficando distribuídos, assim, entre toda a coletividade, os encargos sofridos pelo particular;

3. O fundamento da indenização por prisão indevida é a assunção de responsabilidade, frente ao risco assumido, a que o Estado adere por força da legislação que impõe o dever de indenizar, atribuindo a responsabilidade ao poder público, e tornando imperativa a sua obrigação perante o particular;

4. A responsabilidade estatal é informada pela teoria do risco administrativo,

conforme os ditames constitucionais, de forma que, demonstrando o lesado o nexo de causalidade entre o dano e a ação ou omissão do Estado, representado por seus agentes, ensejará o direito à indenização, cabendo ao Estado voltar-se regressivamente em face de seu funcionário;

5. O Estado Democrático de Direito revela a necessidade da efetivação do que rezam o art. $1^{\circ}$ e seguintes, bem como o art. $37, \S 6^{\circ}$, da Constituição da República e, a partir do momento em que se concretizam esses postulados, tem-se um verdadeiro Estado democrático e de direito. E uma das formas de tornar efetivas tais garantias é o dever que possui o Estado de responder pelos danos causados;

6. Procuramos discorrer sobre as diversas teorias existentes na doutrina a respeito da responsabilidade extracontratual do Estado por danos que seus agentes, nessa qualidade, causarem a terceiros;

7. O direito de obter a reparação de prejuízos está previsto como uma garantia fundamental do indivíduo pela Constituição Federal, independendo de se tratar de erro judiciário ou judicial, que pode ocorrer em qualquer esfera do direito, ou de prisão indevida; 
8. Os erros judiciários e judiciais, bem como a prisão indevida, seja esta excessiva ou cautelar, serão sempre passíveis de indenização, pois, o direito de obter a reparação dos prejuízos é previsto como uma garantia fundamental do indivíduo pela Constituição Federal, abrangendo os danos patrimoniais, morais e pessoais que o cidadão venha a sofrer;

9. Os cidadãos estão submetidos ao julgamento de seus atos pelo Estado e às consequências por ele impostas. Desta forma, não há como lhe tirar a responsabilidade pelos prejuízos que, exercendo a função jurisdicional que chamou para si, causa prejuízos à sociedade;

10. Responsabilidade civil do Estado por atos jurisdicionais;

Este item trata de tema concernente à responsabilidade do Poder Público por ato jurisdicional, ou seja, ato praticado por juiz ou tribunal judiciário em sua função específica de elaboração e entrega da prestação jurisdicional, ato que, viciado, cause dano pessoal, moral ou patrimonial ao administrado; o serviço judiciário consiste em um serviço público, imposto a todos os cidadãos pelo Estado, que deve zelar por certo grau de perfeição tanto na sua organização quanto no seu funcionamento, bem como responder pelos danos daí provenientes. Por isso, pode-se dizer que "a responsabilidade do Estado por atos judiciais, nestes catalogados também os jurisdicionais, é espécie do gênero responsabilidade do Estado por atos decorrentes do serviço público". E os atos do Poder Judiciário, jurisdicionais ou administrativos, são atos das pessoas físicas que exercem o serviço público judiciário, em nome do Estado; portanto, empenham, se danosos, a responsabilidade da pessoa jurídica (Estado) que representam (ARAÚJO, Edmir Netto de. Responsabilidade do Estado por ato jurisdicional, São Paulo: Revista dos Tribunais, 1981, p. 181);

11. A indenização deve corresponder ao valor de avaliação da diminuição sentida pelo lesado em seu patrimônio, seja de natureza material, atingindo o patrimônio da pessoa e consistindo em perda monetária decorrente da sua redução (dano emergente) ou da supressão de possibilidade de seu aumento (lucro cessante), seja moral, a atingir aspectos nãoeconômicos dos bens jurídicos da pessoa; o valor aferido para a indenização deve ser bastante para coibir futuras injustiças por parte do Estado, bem como dirimir, eis que jamais terá o condão de suprimir, a irreparável supressão da liberdade de alguém inocente;

12. Convém ser proposta a ação indenizatória em face do Estado, em razão da responsabilidade objetiva, ao invés de demandar diretamente contra o magistrado, ocasião em que a responsabilidade seria subjetiva. Cumpre ao Estado exercer seu direito de regresso 
contra o magistrado ou órgão colegiado, apenas e tão somente quando estes agirem com dolo ou fraude, caso contrário, deve assumir os erros de seus funcionários;

13. Assim, tanto a pessoa jurídica de direito público quanto a pessoa jurídica de direito privado prestadora de serviço público têm direito de regresso contra seus respectivos agentes responsáveis pelo dano que aquelas foram obrigadas a indenizar;

14. Quando identificado o agente causador do dano, o artigo $37, \S 6^{\circ}$, da Constituição Federal assegura que, caso tenha ele agido com dolo ou culpa, o Estado deve (isso não é uma faculdade, mas um poder-dever irrenunciável e indisponível do Estado) promover o ressarcimento ao erário das despesas havidas com a mencionada indenização, intentando uma ação regressiva contra o servidor responsável, o que, mesmo que da Constituição não constasse, seria assegurado pelo artigo 934 do Código Civil;

15. Abordamos, também, embora resumidamente, o tema que diz respeito ao instituto da denunciação da lide, e qual sua importância frente à ação regressiva;

16. A identificação dos sujeitos que devem integrar o polo passivo da ação indenizatória, para se saber se a demanda pode ser proposta contra o Estado e o agente em litisconsórcio facultativo, se deve ser proposta apenas contra o Estado ou se pode ser proposta apenas contra o agente, e se seria admissível em qualquer caso a denunciação recíproca da lide, deve ser examinada necessariamente a partir de uma distinção fundamental, que decorre do art. 37, § 6 , da Constituição;

17. Se a pretensão inicial deduzida pelo prejudicado funda-se na responsabilidade civil objetiva do Estado, com a arguição da culpa anônima do serviço público, de falha administrativa, de risco da atividade estatal desenvolvida, e somente nessa hipótese - da ação indenizatória ajuizada com fundamento na responsabilidade objetiva do Estado, em razão da falha administrativa, de risco da atividade estatal, de culpa anônima do serviço, de culpa presumida da Administração -, é lícito dizer-se, com Hely Lopes Meirelles, que "a ação de indenização da vítima deve ser ajuizada unicamente contra a entidade pública responsável (acrescente-se, agora, também contra a entidade privada prestadora de serviço público), não sendo admissível a inclusão do servidor (agora agente) na demanda";

18. Não iremos nos ocupar sobre o tema da expressão denunciação da lide, visto que não é objeto desta tese, embora o tenhamos feito apenas superficialmente. A denunciação da lide, ou o instituto da litisdenunciação, é o instituto processual que permite, simultaneamente, um acerto da pretensão principal e da regressiva. A questão é controvertida e, por efeito, passível de grande discussão doutrinária; 
19. Não existindo causa apta para a privação da liberdade pessoal em definitivo, a prisão não é devida, impondo ao Estado o dever de indenizar, que, no direito brasileiro, tem amparo no art. 5', LXXV, da Constituição Federal, verbis: "O Estado indenizar o condenado por erro judiciário, assim como o que ficar preso além do tempo fixado na sentença", ficando distribuídos, assim, entre toda a coletividade, os encargos sofridos pelo particular;

20. O fundamento da indenização por prisão indevida é a assunção de responsabilidade, frente ao risco assumido, a que o Estado adere por força da legislação que impõe o dever de indenizar, atribuindo a responsabilidade ao poder público, e tornando imperativa a sua obrigação perante o particular;

21. Por derradeiros, deixamos aqui nossa posição no sentido de que, quando há um erro judiciário, nos termos do art. 5\%, LXXV, DA CF., e tendo havido prisão processual, a posterior absolvição empenha a responsabilidade civil do Estado à indenização, por danos materiais e morais;

Esse é o entendimento, hoje, de considerável corrente jurisprudencial de nossos tribunais superiores a respeito do tema, da indenização do erro judiciário e da prisão indevida, seja processual ou cautelar, ou, mesmo, definitiva, quando se detecta ter havido erro judiciário. A prisão por erro judiciário ou permanência do preso por tempo superior ao determinado na sentença, de acordo com o art. $5^{\circ}, \mathrm{LXXV}$, da CF, garante ao cidadão o direito à indenização.

Assemelha-se à hipótese de indenizabilidade por erro judiciário, a restrição preventiva da liberdade de alguém que posteriormente vem a ser absolvido. A prisão injusta revela ofensa à honra, à imagem, mercê de afrontar o mais comezinho direito fundamental à vida livre e digna. A absolvição futura revela da ilegitimidade da prisão pretérita, cujos efeitos deletérios para a imagem e honra do homem são inequívocos (notoria non egent probationem); defendemos esse entendimento, embora ao exame das circunstâncias de caso a caso;

22. Como bem se expressou José de Aguiar Dias, quando afirmou que ordinariamente, considera-se erro judiciário a sentença criminal de condenação injusta. Em sentido mais amplo, a definição alcança, também, a prisão preventiva injustificada. Com efeito, não há base para excluí-la do direito à reparação. Se há erro judiciário em virtude da sentença condenatória, haverá também em consequência da prisão preventiva ou detenção. Danos e tragédias decorrem, por igual, de uma e de outros. Onde existe a mesma razão, deve valer a mesma disposição; 
23. Defendemos, nesta tese, que o erro judiciário penal, em seu sentido amplo, abrange, além da sentença condenatória, a prisão preventiva ou processual, ou, ainda, a prisão cautelar injusta, por cujos danos patrimoniais e morais patentes, igualmente, responde o Estado; defendemos também a posição de que os casos de erro judiciário civil igualmente engendram a responsabilidade estatal;

24. Eis, pois, em apertada síntese, o exame que propusemos a respeito da indenização por erro judiciário e prisão indevida, que hoje adquiriu status constitucional no artigo $5^{\circ}$, inciso LXXV, da Constituição da República. Assim, também, seguindo o caminho trilhado por respeitáveis doutrinadores, nacionais e estrangeiros, concordamos em que, "seja voluntário ou involuntário, todo erro que produza consequências danosas - em outras palavras, toda atividade judiciária danosa - deve ser reparado, respondendo o Estado civilmente pelos prejuízos, a ele assegurado o direito de regresso contra o agente público responsável pela prática do ato";

Essa é, pois, a nossa posição, respeitando as posições e entendimentos em sentido contrário. 


\section{BIBLIOGRAFIA}

ALCÂNTARA, Maria Emília Mendes. Responsabilidade ou irresponsabilidade do Estado? In: BANDEIRA DE MELLO, Celso Antônio (coord.). Curso de direito administrativo. São Paulo: Revista dos Tribunais, 1986.

. Responsabilidade do Estado por atos legislativos e jurisdicionais. São Paulo: Revista dos Tribunais, 1988.

. Responsabilidade do Estado na Constituição de 1988. In: BANDEIRA DE MELLO, Celso Antônio (coord.). Direito administrativo na Constituição de 1988. São Paulo: Revista dos Tribunais, 1991, p. 199-205.

ALMEIDA, Arnaldo Quirino de. A responsabilidade do Estado pela prisão ilegal. Revista Consultor Jurídico. Disponível em: www.conjur.com.br. Acesso em: 24 jul. 2005.

ALMEIDA, Caio Eduardo Canguçu. O art. $5^{\circ}$, inciso LVII, da Constituição da República e a prisão anterior à sentença penal condenatória definitiva. Revista de Jurisprudência do Tribunal de Justiça do Estado de São Paulo, São Paulo, v. 125, $4^{\circ}$ bimestre, jul./ago. 1990.

ALVES, Vilson Rodrigues. Responsabilidade civil do Estado por atos dos agentes dos poderes legislativo, executivo e judiciário. Tomos I e II, Campinas, SP: Editora Bookseller, 2001.

AMARAL SANTOS, Moacyr. Primeiras linhas de direito processual civil. São Paulo: Saraiva, 1997.

AMARAL JÚNIOR, José Levi Mello do. Reforma define status jurídico de tratados internacionais. Disponível em: www.conjur.com.br. Acesso em: 29 out. 2008.

Tratados internacionais: reforma nega status constitucional automático a tratado. Disponível em: www.conjur.com.br. Acesso em: 29 out. 2008.

Os tratados internacionais sobre direitos humanos: como ficam após a reforma do Poder Judiciário. Revista Jurídica Consulex, Brasília, v. IX., n. 197, p. 38-39, mar. 2005.

ANNONI, Danielle. Responsabilidade do Estado pela não duração razoável do processo. Curitiba: Juruá Editora, 2009.

ARAS, Vladimir. Diminuição do quadro de instâncias: posição favorável. Carta Forense, março de 2011, p. B 26.

ARAÚJO, Edmir Netto de. Responsabilidade do Estado por ato jurisdicional. São Paulo: Revista dos Tribunais, 1981.

Ilícito administrativo: a comunicabilidade das instâncias penal e administrativa. Revista da Procuradoria Geral do Estado, São Paulo, n. 29, 1988. 
Curso de Direito Administrativo. 5. ed. São Paulo: Saraiva, 2010.

ARAÚJO. Francisco Fernandes de. Do prazo razoável na prestação jurisdicional apud CATOSSI, Vanessa Padilha. Responsabilidade civil do Estado pela demora na prestação jurisdicional. Jus Navigandi, Teresina, ano 12, n. 1351, 14 mar. 2007. Disponível em: <http://jus.uol.com.br/revista/texto/9602>. Acesso em: 31 jan. 2011.

ARDANT, Philippe. La responsabilité de l'état du fait de la fonction juridictionnelle. Paris: LGDJ, 1956.

BACELLAR FILHO, Romeu Felipe. Responsabilidade civil extracontratual das pessoas jurídicas de direito privado prestadoras de serviço público. Interesse Público, Sapucaia do Sul, n. 6, abr./jun., 2000, pp. 11-44.

BANDEIRA DE MELLO, Celso Antônio. Curso de direito administrativo. 24. ed. São Paulo: Malheiros, 2007.

Apontamentos sobre os agentes e órgãos públicos. São Paulo: RT, 1987.

BANDEIRA DE MELLO, Oswaldo Aranha. Princípios gerais de direito administrativo. v. I e II. Rio de Janeiro: Forense, 1979.

BARROS, Romeu Pires de Campos. Processo penal cautelar. Rio de Janeiro: Forense, 1982.

Considerações em torno da prisão em flagrante delito. Revista dos Tribunais, São Paulo, Ano 49, v. n. 301, pp. 24-40, nov. 1960.

BARROSO, Luis Roberto. Interpretação e aplicação da Constituição. 5. ed. São Paulo: Saraiva, 2003.

. Temas de direito constitucional. 2. ed. Rio de Janeiro: Renovar, 2002.

BASILEU, Garcia. Instituições de Direito Penal. v. I, tomo 2. São Paulo: Max Limonad, 1952.

BASTOS, Celso Ribeiro. Curso de direito constitucional. São Paulo: Celso Bastos Ed., 2002.

Elementos de direito constitucional. 2. ed. São Paulo: Saraiva, 1976.

; MARTINS, Ives Gandra da Silva. Comentários à Constituição do Brasil. v. I e VII. São Paulo: Saraiva, 1989.

BAZHUNI, Marco Antonio. Da responsabilidade civil do Estado em decorrência de sua atividade administrativa. Rio de Janeiro: Lumen Juris, 1992.

BECHARA, Fábio Ramazzini. Prisão cautelar. São Paulo: Malheiros, 2005.

BEGLEY, Louis. O Caso Dreyfus - Ilha do Diabo, Guantánamo e o pesadelo da história. São Paulo: Companhia das Letras, 2010. 
BIELSA, Rafael. As vítimas dos erros judiciários nas causas criminais e o direito à reparação. Revista Forense, vol. 105, p. 482.

BIELSA, Rafael. Derecho Administrativo. 5. ed. Buenos Aires: Depalma, 1957.

BRASIL. Supremo Tribunal Federal. Recurso Extraordinário nº 70.121/MG, rel. Min. Djaci Falcão, DJ. 30.03.73. RDA, São Paulo, n. 114, p.298.

BRASIL, Ubiratan. Pesadelos Jurídicos: Semelhanças entre o absurdo jurídico da França do século 19 e Guantánamo inspiram livro. Jornal O Estado de S.Paulo, ed. 02 de janeiro de 2011, caderno "Cultura".

BRÉCHON-MOULÈNES. Les regimes législatifs de responsabilité publique. Paris: Librairie Générale de Droit et de Jurisprudence, 1974.

BÜHRING, Márcia Andréa. A natureza jurídica do poder de polícia é discricionária? 2001. Monografia (Pós-graduação do curso de Mestrado Interinstitucional em Direito) Universidade Federal do Paraná e Universidade de Caxias do Sul, Curitiba, 2002.

Responsabilidade civil extracontratual do Estado. São Paulo: Thomson-IOB, 2004.

BUSTAMANTE ALSINA, Jorge. Teoria general de la responsabilidad civil. 9. ed. atual. e ampl. Buenos Aires: Abeledo-Perrot, 1997.

BUZAID, Alfredo. Da responsabilidade do juiz. Revista de Processo, São Paulo, n. 9, p.15.

CAETANO, Marcello. Manual de direito administrativo. 9. ed. Coimbra: Coimbra, 1970.

Princípios fundamentais do direito administrativo. Rio de Janeiro: Forense, 1989.

CAHALI, Yussef Said. Responsabilidade civil do Estado. 3. ed. São Paulo: Revista dos Tribunais, 2007.

. Dano e indenização. São Paulo: Ed. Revista dos Tribunais, 1980.

CALAMBREDI, Pietro. Eles, os juízes, vistos por um advogado. São Paulo: Martins Fontes, 2000.

Dano e indenização. São Paulo: RT, 1980.

CAMARGO, Luis Antonio de. A responsabilidade civil do Estado e o erro judiciário. Porto Alegre: Síntese, 1999.

CAMPOS, Asér Martins de Souza; CAMPOS JÚNIOR, Asér de Souza. Breves anotações sobre a prova e erros judiciários. [s.l.: s.n.],1984.

CAMPOS, Francisco. Direito constitucional. Rio de Janeiro: Freitas Bastos, 1956.

CAMPOS BARROS, Romeu Pires. Considerações em torno da prisão em flagrante delito. Revista dos Tribunais. São Paulo, v. 49, n. 301, pp. 24-40, nov. 1960. 
CANÇADO TRINDADE, Antonio Augusto. Proteção internacional dos direitos humanos nos planos nacional e internacional: perspectivas brasileiras. Brasília/San José da Costa Rica: IIDH/F. Naummann-Stiftung, 1992.

A incorporação das normas internacionais de proteção dos direitos humanos no direito brasileiro. Brasília/San José da Costa Rica: Instituto Interamericano de Direitos Humanos, Comitê Internacional da Cruz Vermelha, 1996.

Direitos e garantias individuais no plano internacional, In: Assembleia Nacional Constituinte: Atas das Comissões, v. I, n. 66 (supl.), 27.5.1987.

CANOTILHO, José Joaquim Gomes. Direito constitucional e teoria da Constituição. 3. ed. Coimbra: Almedina, 1999.

; MOREIRA, Vital. Constituição da República portuguesa anotada. 3. ed. Coimbra: Coimbra, 1993. 1974.

O problema da responsabilidade do Estado por atos lícitos. Coimbra: Coimbra,

CAPPELLETTI, Mauro. Juízes irresponsáveis? Trad. Carlos Alberto Álvaro de Oliveira. Porto Alegre: Sérgio Antonio Fabris, 1989.

CAPEZ, Fernando. Lei $\mathrm{n}^{\circ}$ 12.403/2011 e prisão provisória: questões polêmicas. Boletim Informativo ano 8, $\mathrm{n}^{\circ}$ 46, maio/junho/julho de 2011: Edição da Escola Superior do Ministério Público de São Paulo, p. 4-7.

CARDOSO, Hélio Apoliano. Indenização em face da morosidade e erro do judiciário e suas controvérsias. Revista Cearense Independente do Ministério Público. Ano I - n⿳0 $03-$ Outubro/1999, p. 126.

CARVALHO, Jéferson Moreira de. Prisão e liberdade provisória. São Paulo: Juarez de Oliveira, 1999.

CARVALHO NETO, Inácio de. Responsabilidade do Estado por atos de seus agentes. São Paulo: Atlas, 2000.

CASTRO, Guilherme Couto e. A responsabilidade civil objetiva no direito brasileiro. 2. ed. Rio de Janeiro: Forense, 1997.

CATARINO, Luis Guilherme. A responsabilidade do Estado pela administração da justiça. Coimbra: Almedina, 1999.

CAVALCANTI, Amaro. Responsabilidade civil do Estado. 2. ed. Rio de Janeiro: Borsoi, 1956.

CAVALCANTI, Themistocles Brandão. Tratado de direito administrativo. 5. ed. Rio de Janeiro: Freitas Bastos, 1964. 
CAVAlLIERI FILHO, Sérgio. Programa de responsabilidade civil. 2. ed. São Paulo: Malheiros, 1998.

Programa de responsabilidade civil. 9. ed. São Paulo: Atlas, 2010.

CERQUEIRA, Manoel de Castro. A responsabilidade objetiva das pessoas de direito público interno. Revista de Direito da Procuradoria Geral. São Paulo, v. 2, p. 199.

CHEVALLIER, Jean-Jacques. As grandes obras políticas de Maquiavel a nossos dias. Tradução de Lygia Cristina, revista por André Praça de Souza Telles. 8. ed. Rio de Janeiro: Agir, 2002.

CICOTE, Luiz Eduardo. Responsabilidade civil do Estado perante os condenados beneficiados pelo regime aberto na sentença, mas que cumpriram pena no regime fechado por falta de casa do albergado ou estabelecimento congênere. In: $R T$ 776/485.

CINTRA, Antonio Carlos Araújo; GRINOVER, Ada Pellegrini; DINAMARCO, Cândido Rangel. Teoria geral do processo. 19. ed. São Paulo: Malheiros, 2003.

CLÈVE, Clèmerson Merlin. Atividade legislativa do Poder Executivo no Estado contemporâneo e na Constituição de 1988. São Paulo: RT, 1993.

COTRIM NETO, Alberto Bittencourt. Da responsabilidade do Estado por atos de juiz em face da Constituição de 1988. Revista Trimestral de Direito Público. São Paulo, n. 1, p. 31-49, jan./mar. 1993.

COUTO E SILVA, Almiro do. A responsabilidade extracontratual do Estado no direito brasileiro. Revista do Direito Administrativo. Rio de Janeiro, n. 203, p. 19-41, out./dez. 1995.

CRETELLA JÚNIOR, José. Curso de direito administrativo. 18. ed. Rio de Janeiro: Forense, 2003.

. O Estado e a obrigação de indenizar. 2. ed. Rio de Janeiro: Forense, 2002.

. Tratado de direito administrativo. v. VIII. Rio de Janeiro: Forense, 1972.

Responsabilidade civil do Estado legislador. In: CAHALI, Yussef S. (Coord.). Responsabilidade civil: doutrina e jurisprudência. São Paulo: Saraiva, 1998.

. Responsabilidade do Estado por atos judiciais. RDA, Rio de Janeiro, n. 99, p. 13-32, jan./mar. 1970.

. Manual de direito administrativo. 7. ed. Rio de Janeiro: Forense, 2005. 1989.

Comentários à Constituição de 1988. v. 2. Rio de Janeiro: Forense Universitária,

Responsabilidade do Estado por atos judiciais. Revista Forense, Rio de Janeiro, n. 230, pp. 36-46, abr./jun., 1970. 
. Crimes e julgamentos famosos. São Paulo: Revista dos Tribunais, 2007.

DALLARI, Adilson de Abreu. Regime constitucional dos servidores públicos. 2. ed. São Paulo: RT, 1990.

DALLARI, Dalmo de Abreu. O poder dos juizes. São Paulo: Saraiva, 1996.

DAUDT, Edmar Vianei Marques. Pressupostos da responsabilidade civil do Estado. Revista Justiça do Direito, São Paulo, v. 9, n. 9, pp. 169-188, 1996.

DELGADO, José Augusto. Responsabilidade civil do Estado pela demora na prestação jurisdicional. Paraná Judiciário, Paraná, n. 6, v. 8, pp. 29-36, 1983.

Responsabilidade do Estado: responsabilidade civil do Estado ou responsabilidade da Administração, a demora na entrega da prestação jurisdicional. Revista Jurídica, Porto Alegre, v. 4, n. 226, pp. 5-26, ago. 1996.

DELMANTO JÚNIOR, Roberto. As modalidades de prisão provisória e seu prazo de duração. 2. ed. Rio de Janeiro: Renovar, 2001.

DELVOLVÉ, Pierre. L'acte Administratif. Paris: Daliz, 1983.

DERGINT, Augusto do Amaral. Responsabilidade do Estado por atos judiciais. São Paulo: RT, 1995.

DI PIETRO, Maria Sylvia Zanella. Direito administrativo. 24. ed. São Paulo: Atlas, 2011.

Responsabilidade do Estado por atos jurisdicionais. Revista de Direito Administrativo, Rio de Janeiro, n. 198, pp. 85-96, 1994.

. Responsabilidade administrativa do servidor público. Gênesis - Revista de Direito Administrativo Aplicado, Curitiba, n. 4, pp. 29-36, mar. 1995.

DIAS, José de Aguiar. Da responsabilidade civil do Estado. Rio de Janeiro: Forense, 1999.

Da responsabilidade civil. 11. ed. Rio de Janeiro: Renovar, 2006.

DIAS, Ronaldo Brêtas de Carvalho. Responsabilidade do Estado pela função jurisdicional. Belo Horizonte: Del Rey, 2004.

DINAMARCO, Cândido R. Fundamentos do processo civil moderno. São Paulo: RT, 1986. 2001.

Fundamentos do processo civil moderno. Tomo II. 4. ed. São Paulo: Malheiros,

DINIZ, Danielle Alheiros. Responsabilidade civil do Estado pela morosidade na prestação jurisdicional. In: Jus Navigandi, Teresina, ano 10, n. 563, 21 jan. 2005. Disponível em: <http://jus.uol.com.br/revista/texto/6205>. Acesso em: 12 nov. 2010. 
DINIZ, Maria Helena. Compêndio de introdução à ciência do direito. 14. ed. São Paulo: Saraiva, 2001.

. Curso de direito civil brasileiro. 7 v. 16. ed. São Paulo: Saraiva, 2002.

DREYFUS, Alfred - Cinq années de ma vie - 1894-1899. Paris: La Découverte/Poche, 2006.

DROMI, José Roberto. Instituciones de derecho administrativo. Buenos Aires: Astrea, 1973. Manual de derecho administrativo. v. 2. Buenos Aires: Astrea, 1987.

DUEZ, Paul. La responsabilité de la puissance publique: en dehors du contrat. 2. ed. Paris: Dalloz, 1938.

La responsabilité de la puissance publique : en dehors du contrat. Paris: Librairie Dalloz, 1927.

; DEBEYRE, Gui. Traité de Droit Administratif. Paris : Librairie Dalluz, 1952.

ESTEVES, Júlio César dos Santos. Responsabilidade civil do Estado por ato legislativo. Belo Horizonte: Del Rey, 2003.

FACHIN, Zulmar. Responsabilidade patrimonial do Estado por ato jurisdicional. Rio de Janeiro: Renovar, 2001.

FAGUNDES, Miguel Seabra. O controle dos atos administrativos pelo Poder Judiciário. 3. ed. Rio de Janeiro: Forense, 1957.

O controle dos atos administrativos pelo Poder Judiciário. São Paulo: Saraiva, 1984.

FALCÃO, Alcino Pinto. Comentários à Constituição. Rio de Janeiro: Freitas Bastos, 1990, p. 295.

FARIA, Edimur Ferreira de. Curso de direito administrativo positivo. 3. ed. Belo Horizonte: Del Rey, 2000.

FERNANDES, Antonio Scarance. Prisão temporária e "fermo": estudo comparativo. Fascículos de Ciências Penais, Porto Alegre, v. 5, n. 3, p. 78-89, jul./set. 1992.

Processo penal constitucional. 4. ed. São Paulo: RT, 2005.

FERREIRA, Antonio Carlos. Responsabilidade civil por atos da administração pública. São Paulo: Alfabeto Jurídico, 2002.

FERREIRA FILHO, Manoel Caetano. Da responsabilidade civil do Estado. Revista de Informação Legislativa, Brasília, v. 25, n. 100, pp. 323-336, out./dez., 1988.

FERREIRA FILHO, Manoel Gonçalves. Comentários à Constituição brasileira de 1988. 2. ed. São Paulo: Saraiva, 1997. v. 1. 
Curso de direito constitucional. 32. ed. atual. São Paulo: Saraiva, 2006.

FIGUEIREDO, Lúcia Valle. Curso de direito administrativo. 7. ed. São Paulo: Malheiros, 2004.

Responsabilidade dos agentes políticos e dos servidores. Revista de Direito Administrativo, Rio de Janeiro, v. 50, n. 196, p. 36-42, abr./jun. 1994.

FREITAS, Maria Helena d'Arbo Alves de. O Estado legislador responsável. Revista de Informação Legislativa, Brasília, n. 128, p. 285-295, out./dez. 1995.

FREITAS, Sérgio Henrique Zandona. Responsabilidade civil do Estado por ato administrativo. In: MOTTA, Carlos Pinto Coelho (Coord.). Curso de direito administrativo. Belo Horizonte: Del Rey, 1999.

FRIEDE, Reis. Curso de direito administrativo: em forma de perguntas, respostas e diagramas explicativos. 2. ed. Rio de Janeiro: Forense, 1996.

FUDOLI, Rodrigo de Abreu. Uso de algemas: a Súmula Vinculante $\mathrm{n}^{\circ}$ 11, do STF. Jus Navigandi, Teresina, ano 12, n. 1875, 19 ago. 2008. Disponível em: <http://jus2.uol.com.br/doutrina/texto.asp?id=11625>. Acesso em: 04 dez. 2010 .

GARCIA, Mônica Nicida. Responsabilidade do agente público. Belo Horizonte: Fórum, 2004.

GASPARINI, Diogenes. Direito administrativo. 10. ed. São Paulo: Saraiva, 2005.

GAZOTO, Luís Wanderley, Responsabilidade estatal por atos jurisdicionais, Revista de Doutrina e Jurisprudência [Tribunal de Justiça do Distrito Federal e dos Territórios], 60:59/60, maio/ago. 1999.

GIACOMOLLI, Nereu José. Reformas do Código de Processo Penal: Considerações críticas. Rio de Janeiro: Lúmen Júris, 2008.

GOMES, Luiz Flávio. Direito de apelar em liberdade (conforme a Constituição Federal e a Convenção Americana sobre Direitos Humanos): doutrina e jurisprudência. São Paulo: RT, 1994.

GOMES FILHO, Antonio Magalhães. Presunção de inocência e prisão cautelar. São Paulo: Saraiva, 1991.

; GRINOVER, Ada Pellegrini; FERNANDES, Antonio Scarance. Recursos no processo penal. 3. ed. São Paulo: RT, 2001.

Prisão cautelar e o princípio da presunção de inocência. Fascículos de Ciências Penais, Porto Alegre, v. 5, n. 1, p. 17-27, jun./mar. 1992.

Direito à Prova no Processo Penal. São Paulo: Revista dos Tribunais, 1997.

GONÇALVES, Carlos Roberto. Responsabilidade civil. 9. ed. São Paulo: Saraiva, 2005. 
GRECO FILHO, Vicente. A denunciação da lide: sua obrigatoriedade e extensão. Justitia, São Paulo, n.94, p.9-17, 1976.

GROTTI, Dinorá Adelaide Musetti. Inviolabilidade do Domicílio na Constituição. São Paulo: Malheiros Editores, 1993. 2003.

Serviço Público e a Constituição Brasileira de 1988. São Paulo: Malheiros Editores,

GUAGLIARIELLO, Glaucio. Efetividade da jurisdição: razoável duração do processo. In: Jus Navigandi, Teresina, ano 12, n. 1425, 27 maio 2007. Disponível em: http://jus.uol.com.br/revista/texto/9772. Acesso em: 9 dez. 2010.

GUALAZZI, Eduardo Lobo Botelho. Justiça administrativa. São Paulo: RT, 1986.

GUETTIER, Christophe. La responsabilité administrative. Paris: Librairie Générale de Droit et de Jurisprudence, 1959.

GUIMARÃES, Mário. Estudos de direito civil. São Paulo: Martins, 1947.

HAURIOU, Maurice. Précis de droit administratif et de droit public. 11. ed. Paris: Sirey, 1927.

HENTZ, Luis Antonio Soares. Indenização da prisão indevida. São Paulo: Ed. Leud, 1996.

Responsabilidade do Estado por prisão indevida. Revista dos Tribunais, São Paulo, v. 730, pp. 68-79, ago., 1996.

Indenização do erro judiciário. São Paulo: Leud, 1996.

Responsabilidade do Estado por prisão indevida. Jus Navigandi, Teresina, ano 5,

n. 42, 1 jun. 2000. Disponível em: http://jus.uol.com.br/revista/texto/1092. Acessado em: 28 maio de 2011.

JARDIM, Afrânio Silva. A prisão no curso do processo em face da nova Constituição. Revista dos Tribunais, São Paulo, v. 14, n. 54, pp. 256-269, abr./jun. 1989.

JELLINEK, George. Teoria general del Estado. Tradução de la segunda edición alemana por Fernando de los Rios Urruti. Granada: Comares, 2000.

JESUS, Damásio Evangelista de. Direito penal. v. 1. São Paulo: Saraiva, 1986.

JUCOVSKY, Vera R. S. Responsabilidade civil do Estado pela demora na prestação jurisdicional. São Paulo: Juarez de Oliveira, 1999.

KELSEN, Hans. General theory of law and state. Nova Iorque: Russel \& Russel, 1961. Jurisdição constitucional. São Paulo: Martins Fontes, 2003. 
La giustizia constituzionale. Tradução de Sérgio Resende de Barros. Milão: Giuffrè, 1981.

. Teoria pura do direito. Tradução de João Batista Machado. 4. ed. Coimbra: Arménio Amado, 1976.

LASPRO, Oreste Nestor de Souza. A responsabilidade civil do juiz. São Paulo: RT, 2000.

LAZZARINI, Álvaro. Responsabilidade civil do Estado por atos omissivos de seus agentes. RJTJSP, 117:8.

LEIVAS, Paulo Gilberto Cogo. Responsabilidade civil do Estado por atos legislativos. Boletim Científico da Escola Superior do Ministério Público da União, Brasília, v. 1, n. 1, pp. 111-118, out./dez. 2001.

LENZ, Eduardo Thompson Flores. Responsabilidade do Estado por atos judiciais. In: Revista de Direito Administrativo, vol, 210, p. 147-158, Rio de Janeiro: out./dez.1997.

LESSA, Pedro. Do Poder Judiciário. Rio de Janeiro: Livr. Francisco Alves, 1915.

LIEBMAN, Eurico Tullio. Eficácia e autoridade da sentença. Rio de Janeiro: Forense, 1981.

LOUREIRO FILHO, Lair da Silva. Responsabilidade pública por atividade judiciária. São Paulo: RT, 2005.

LUIS CARLOS, Làzinha. Erros judiciários. v. I. São Paulo: São Paulo, 1973.

MARQUES, José Frederico. Tratado de direito penal. v. 3. São Paulo: Saraiva, 1956.

Elementos de direito processual penal. v. IV. Campinas: Bookseller, 1997.

MEDAUAR, Odete. Direito administrativo moderno. 12. ed. São Paulo: RT, 2008.

Direito administrativo em evolução. 2. ed. São Paulo: RT, 2003.

MEDEIROS, Rui. Ensaio sobre a responsabilidade do Estado por actos legislativos. Coimbra: Almedina, 1992.

MÉDICI, Sérgio de Oliveira. Revisão criminal. 2. ed. São Paulo: Revista dos Tribunais, 2000.

MEIRELLES, Hely Lopes. Direito administrativo brasileiro. 37. ed. São Paulo: Malheiros, 2011.

MEIRELLES, Lenilma Cristina Sena de Figueiredo. Responsabilidade civil do Estado por prisão ilegal. Jus Navigandi, Teresina, ano 9, n. 505, 24 nov. 2004. Disponível em: http://jus.uol.com.br/revista/texto/5961. Acesso em: 27 maio 2011 e em 23 out. 2011.

MELlo, Celso Antônio Bandeira de. Curso de Direito Administrativo. 24. ed. São Paulo: Malheiros, 2007. 
MELLO FILHO, José Celso. Constituição Federal anotada. São Paulo: Saraiva, 1986.

MENDES, Gilmar Ferreira. Direitos fundamentais e controle de constitucionalidade. 3. ed. São Paulo: Saraiva, 2004.

O papel do Senado Federal no controle de constitucionalidade: um caso clássico de mutação constitucional. Cadernos de Direito da Universidade Metodista de Piracicaba, sob a coordenação do Prof. Sérgio Resende de Barros, no prelo.

MENDES JÚNIOR, Onofre. Natureza da responsabilidade da administração pública. Belo Horizonte, 1961.

MENDES JÚNIOR, João. Direito judiciário brasileiro. 5. ed. São Paulo-Rio: Freitas Bastos, 1960.

MENDONÇA, Fabiano André de Souza. Responsabilidade do Estado por ato judicial violador da isonomia. São Paulo: Juarez de Oliveira, 2000.

Responsabilidade do Estado por ato judicial inconstitucional, In: $R T$ 738/12-31.

MICHOUD, Léon. De la responsabilité de l'État a raison des fautes de sés agents. Revue du Droit Publique et de la Science Politique em France et à l'étranger, Paris: M. Giardi \& E. Brière, pp. 253-255,1895.

MIRABETE, Julio Fabbrini. Processo penal. 14. ed. São Paulo: Atlas, 2003.

MONTEIRO, Washington de Barros. Curso de direito civil: parte geral. v. I. 35. ed. São Paulo: Saraiva, 2007.

MONTENEGRO, Antonio Lindbergh C. Ressarcimento de danos. 4. ed. Rio de Janeiro: Âmbito, 1992.

MONTESQUIEU, Charles-Louis de Secondat, Baron de la Brède et de. O espírito das leis. Tradução Cristina Murachco. 2. ed. São Paulo: Martins Fontes, 2000.

MORAES, Alexandre de. Direitos humanos fundamentais. 3. ed. São Paulo: Atlas, 2000. Direito constitucional administrativo. São Paulo: Atlas, 2002. . Constituição do Brasil interpretada. São Paulo: Atlas, 2002.

Direito constitucional. 8. ed. São Paulo: Atlas, 2000.

MOREIRA NETTO, Diogo de Figueiredo. Curso de direito administrativo. 14. ed. rev., ampl. e atual. Rio de Janeiro: Renovar, 2005.

MOTA, Maurício Jorge Pereira da. Responsabilidade civil do Estado legislador. Rio de Janeiro: Lumen Juris, 1999. 
MOURÃO, Jacira Nunes. Responsabilidade civil do Estado por actos jurisdicionais. Revista de Direito Civil - imobiliário, agrário e empresarial. São Paulo: RT, n. III, ano 2, p. 6582, jan./mar., 1978.

NANNI, Giovanni Ettore. A responsabilidade civil do juiz. São Paulo: Max Limonad, 1996.

NASCIMENTO, Tupinambá Miguel Castro do. Responsabilidade civil do Estado. Rio de Janeiro: Aide, 1995.

NEGRÃO, Theotonio. Código de Processo Civil e legislação processual em vigor. 31. ed. São Paulo: Saraiva, 2000.

NERY, Nelson; ANDRADE, Rosa Maria de. Código de Processo Civil comentado. 4. ed. São Paulo: RT, 1999.

NERY JUNIOR, Nelson. Princípios do Processo Civil na Constituição Federal. São Paulo: Revista dos Tribunais, 1992.

Proibição de prova ilícita: novas tendências do direito. In: PENTEADO, Jaques de Camargo (Coord.). Justiça Penal (críticas e sugestões). São Paulo: Revista dos Tribunais, 1997.

. Proibição da prova ilícita - Novas tendências do direito (CF, art.5 $\left.{ }^{\circ}, \mathrm{LVI}\right)$. In: MORAES, Alexandre de (coord.). Os 10 Anos da Constituição Federal. São Paulo: Revista dos Tribunais, 1999.

Princípios fundamentais: teoria geral dos recursos. 3. ed. São Paulo: Revista dos Tribunais, 1996.

NOBRE JÚNIOR, Edílson Pereira. Responsabilidade civil do Estado e denunciação da lide. Revista Jurídica, Porto Alegre, n. 248, pp. 142-149, jun. 1998.

OLIVEIRA, Josivaldo Felix de. A responsabilidade do Estado por ato lícito. São Paulo: Habeas, 1998.

PANTALEÃO, Juliana F.; MARCOCHI, Marcelo C. Indenização: erro judiciário e prisão indevida. Jus Navigandi, Teresina, ano 9, n. 416, 27 ago. 2004. Disponível 5642>. Acesso em: 4 jun. 2011.

PENTEADO, Jaques de Camargo. Tempo da prisão: breves apontamentos. Revista da Faculdade de Direito de São Bernardo do Campo. No 8, 2002, p. 231-266.

PEREIRA, Caio Mario da Silva. Responsabilidade civil. 2. ed. Rio de Janeiro: Forense, 1990. Instituições de direito civil. Rio de Janeiro: Forense, 1966.

PIERANGELlI, José Henrique. Processo Penal. Evolução Histórica e Fontes Legislativas. Bauru: Editora Jalovi, 1983. p. 331/332. 
PRIETO, Andre Luiz. O uso abusivo de algemas e a tríplice responsabilidade . Jus Navigandi, Teresina, ano 12, n. 1878, 22 ago. 2008. Disponível em: http://jus2.uol.com.br/doutrina/texto.asp?id=11629. Acessado em: 02 dez. 2010.

PINTO FERREIRA, Luis. Preâmbulo. Enciclopédia Saraiva do Direito. v. LIX. São Paulo: Saraiva, 1977.

PITOMBO, Sérgio Marcos de Moraes. Acórdão, Apel. Cível n. 037.029.5/6 - 00, $7^{a}$ Câm. TJSP - 13.09.1999, Rel. Sérgio Pitombo.

PONTES DE MIRANDA, F. C. Comentários ao Código de Processo Civil. v. 7. Rio de Janeiro: Forense, 1974.

PORTO, Hermínio Alberto Marques. Júri: procedimentos e aspectos do julgamento. 10. ed. São Paulo: Saraiva, 2001.

PORTO, Mário Moacyr. Temas de responsabilidade civil. São Paulo: Revista dos Tribunais, 1989.

Responsabilidade do Estado pelos atos dos seus juízes. RT, 563:9.

QUEIROZ, Odete Novais Carneiro. Prisão Civil e os direitos humanos. São Paulo: Revista dos Tribunais, 2004.

QUIRINO, Arnaldo. Prisão ilegal e responsabilidade civil do Estado, São Paulo: Atlas, 1999.

RÁO, Vicente. Ato jurídico. 2. ed. São Paulo: Saraiva, 1979.

RESTIFFE NETO, Paulo; RESTIFFE, Paulo Sérgio. Prisão civil do depositário infiel em face da derrogação do art. 1.287 do Código Civil, pelo Pacto de São José da Costa Rica. Revista dos Tribunais, São Paulo, v. 756, p. 37-52, out. 1998.

RIBEIRO, Ana Cecília Rosário. Responsabilidade civil do Estado por atos jurisdicionais. São Paulo: LTr, 2002.

RIVERO, Jean. Droit administrative. 3 ed. Paris: Dalloz, 1965.

RIVERO, Jean; WALINE, Jean. Droit administrative. 18. ed. Paris: Dalloz, 2000.

ROCHA, Carmem Lúcia Antunes. Observações sobre a responsabilidade patrimonial do Estado. Revista de Informação Legislativa, Brasília, ano 28, n. 111, pp.79-122, jul./set. 1991.

Princípios constitucionais da administração pública. Belo Horizonte: Del Rey, 1994. Princípios constitucionais dos servidores públicos. São Paulo: Saraiva, 1999.

ROCHA JÚNIOR, José Jardim. Problemas com o governo dos juízes: sobre a legitimidade democrática do "judicial review". Revista de Informação Legislativa, Brasília, v. 38, n. 151, pp. 255-278, jul./set. 2001. 
RODRIGUES, Silvio. Direito civil. v. 1. 9. ed. São Paulo: Saraiva, 1979.

. Direito civil: responsabilidade civil. v. 4. 7. ed. São Paulo: Saraiva, 1983.

302-303.

Direito civil: responsabilidade civil. 7. ed. São Paulo: Saraiva, 1979, v. 5. n. 7, p.

ROZAS, Luiza Barros. Responsabilidade civil do Estado por atos jurisdicionais. Revista da FADUSP 99/782.

SALAZAR, Alcino de Paula. Responsabilidade do poder público por atos judiciais. Rio de Janeiro: Canton \& Reile, 1941.

SAMPAIO, Rogério Marrone de Castro. Direito civil: responsabilidade civil. São Paulo: Atlas, 2000.

SANGUINÉ, Odone. Prisão provisória e princípios constitucionais. Fascículos de Ciências Penais, Porto Alegre, v. 5, n. 2, p. 96-124, abr./mar. 1992.

SÉ, João Sento. Responsabilidade civil do Estado por atos judiciais. São Paulo: Bushatsky, 1976.

Responsabilidade civil do Estado pela atividade judiciária na Constituição de 1988. Revista da Faculdade de Direito da UFBA, Bahia, v. 35, 1991, p. 63-64. Edição em homenagem ao centenário da Faculdade de Direito da UFBA, coordenada por Antonio Carlos de Oliveira.

SERRANO JÚNIOR, Odoné. Responsabilidade civil do estado por atos judiciais. Curitiba: Juruá, 1996.

Responsabilidade extracontratual do Estado por atos judiciais. Revista da Faculdade de Direito de Curitiba, Curitiba, v. 11, n. 9, pp. 57-187, 1995.

SILVA, De Plácido e. Vocabulário jurídico. v. 2. Rio de Janeiro: Forense, 1963.

SILVA, José Afonso da. Curso de direito constitucional positivo. 27. ed. São Paulo: Malheiros, 2006.

SILVA, Juary C. A Responsabilidade do Estado por atos judiciários e legislativos. São Paulo: Saraiva, 1985.

. Responsabilidade civil do Estado por atos jurisdicionais, em RT 351, 1965 (52-66-140-163).

A responsabilidade civil do juiz. São Paulo: RT, 2000.

Responsabilidade civil do Estado por atos jurisdicionais, em RDP 20/178 e 179.

SILVA, Marco Antonio Marques da. Acesso à justiça penal e Estado democrático de direito.

São Paulo: Juarez de Oliveira, 2001. 
. (coord.). Tratado temático de processo penal. São Paulo: Juarez de Oliveira, 2002.

2006.

(coord.). Processo penal e garantias constitucionais. São Paulo: Quartier Latin,

SILVA FILHO, Artur Marques da. Juízes irresponsáveis? Uma indagação presente. $R T$, n. 674, São Paulo, RT, p. 70-80, dez. 1991.

SOUZA, José Guilherme de. A responsabilidade civil do Estado pelo exercício da atividade judiciária. Ed. Revista dos Tribunais, São Paulo, v. 652, p. 29-49, fev. 1990.

STOCO, Rui. Tratado de responsabilidade civil. 6. ed. São Paulo: RT, 2004.

Responsabilidade civil e sua interpretação doutrinária e jurisprudencial. 5. ed. São Paulo: RT, 2001.

Responsabilidade do Estado por erro judiciário. ,n. 21, São Paulo, RT, p. 91-101, jan.-mar. 1998.

TÁCITO, Caio. Tendências atuais sobre a responsabilidade civil do Estado. Revista de Direito Administrativo, São Paulo, n. 55, pp. 262-271, jan./mar., 1959.

TESSEROLI FILHO, Nourmirio Bittencourt. Teoria dos frutos da árvore envenenada, Disponível em:

http://artigos.netsaber.com.br/resumo_artigo_8551/artigo_sobre_teoria_dos_ frutos_da_Árvore_envenenada. Acesso em: 13.01.2011.

TESSIER, Georges. La responsabilité de la puissance publique. Paris: Paul Dupont, 1906.

THEODORO JÚNIOR, Humberto. Processo cautelar. 9. ed. São Paulo: Universitária de Direito, 1987.

TOJAL, Sebastião Botto de Barros. Teoria geral do Estado. São Paulo: Forense, 1997.

; CAETANO, Flávio Crocce. Competência e prerrogativa de foro em ação civil de improbidade administrativa, In: BUENO, Cássio Scarpinella; PORTO FILHO, Pedro Paulo de Rezende (coord.). Improbidade administrativa: questões polêmicas e atuais. 2. ed. São Paulo: Malheiros, 2003.

TOLEDO, Francisco de Assis. Princípios básicos de direito penal. São Paulo: Saraiva, 1987.

TORON, Alberto Zacarias. A Constituição de 1988 e o conceito de bons antecedentes para apelar em liberdade. Revista Brasileira de Ciências Criminais, São Paulo, v. 1, n. 4, pp. 70-80, out./dez. 1993.

Diminuição do quadro de instâncias: posição contrária. Carta Forense, março de 2011 , p. B 26.

TOURINHO FILHO, Fernando da Costa. Processo penal. 33. ed. São Paulo: Saraiva, 2011. 
Da prisão e da liberdade provisória. Revista Brasileira de Ciências Criminais, São Paulo, Revista Dos Tribunais, ano 2, nº 7, julho-setembro de 1994., p. 73.

TROTABAS, Louis. La responsabilité de l'Etat em droit interne e le respect de la propriété privée. In: Introduction à l'étude Du Droit Comparé. Darmstadt, Detlev Auvermann, 1973, v. 3, PP. 46-53 (Recueil d'études Edouard Lamberty).

TUCCI, José Rogério Cruz e. Tempo e processo: uma análise empírica das repercussões do tempo na fenomenologia processual (civil e penal). São Paulo: RT, 1997.

TUCCI, Rogério Lauria. Direitos e garantias individuais no processo penal brasileiro. 2. ed. São Paulo: Saraiva, 2004.

. Presunção de inocência e prisão provisória. Fascículos de Ciências Penais, Porto Alegre: Fabris, v. 5, n. 2, p. 133-135, 1992.

Do mandado de segurança contra ato jurisdicional penal. São Paulo: Saraiva, 1978.

VELLOSO, Carlos Mário da Silva. Responsabilidade civil do Estado. Revista de Informação Legislativa, Brasília, v. 24, n. 96, pp. 233-252, 1987.

VENDRAMEL, Aparecida. Responsabilidade extracontratual do Estado. São Paulo: Themis, 2000.

VENOSA, Sílvio de Salvo. Direito civil. 4. ed. São Paulo: Atlas, 2004.

VILLA, Leguina. La responsabilidad civil de la administración pública. Madrid: Tecnos, 1970.

VILLELA, Álvaro. A revisão no processo criminal. Coimbra: [s.n.], 1897.

WALD, Arnoldo. Os fundamentos da responsabilidade civil do Estado. In: Revista de Informação Legislativa, Brasília, ano 30, n. 117, p. 16, jan./mar. 1993.

WALINE, Marcel. Droit Administratif. 9. ed. Paris: Sirey, 1963.

WEMBIER, Luiz Rodrigues. A responsabilidade civil do Estado decorrente de atos jurisdicionais. Revista dos Tribunais, v. 633, p. 34.

XAVIER, Márcio Coelho. Fundamentos da responsabilidade civil estatal. Brasília: OAB, 2005

ZANCANER, Weida. Da responsabilidade extracontratual da administração pública. São Paulo: RT, 1981.

ZOLA, Émile. J'accuse! Paris: Labibliothèque Gallimard, 2003. 